\title{
Lavandula stoechas essential oils protect against Malathion-induces reproductive disruptions in male mice
}

\author{
Slimen Selmi*, Kais Rtibi, Dhekra Grami, Hichem Sebai and Lamjed Marzouki
}

\begin{abstract}
Background: The current study was conducted to evaluate the protective effect of Lavandula stoechas essential oils (LSEO) against malathion (M) exposure-caused reprotoxicity in male mice as well as the possible mechanisms implicated in such protection.

Methods: Six-eight-week-old male mice weighting 25-30 g were used and divided into four groups: normalcontrol, LSEO (50 mg/kg, b.w.), malathion (200 mg/kg, b.w.) and malathion + LSEO treated mice. Malathion was emulsioned in corn oil and per orally administered for 30 days. LSEO was daily administrated during the same period. LSEO chemical identification was done by Gas chromatography-mass spectrometry (GC-MS). Reproductiondamages and LSEO-benefits were assessed using histopathological, biochemical and steroidogenesis gene expression disruptions and improvements.

Results: The GC-MS analysis, allowed to the identification of 25 bioactive compounds in MCEO. In vivo, we firstly found that malathion exposure induced a clear reprotoxicity as assessed by a significant-decrease $(P<0.05)$ of testis/epididymis relative weights, serum testosterone level and reproductive performance. Malathion also produced lipoperoxidation, thiol $(-\mathrm{SH})$ groups decrease as well as a significant-depletion $(P<0.05)$ of antioxidant enzyme activities such as catalase (CAT) and glutathione peroxidase (GPx), total superoxide dismutase (SOD), Cu/Zn-SOD and $\mathrm{Mn}-\mathrm{SOD}$ in testis and epididymis. The histopathological examination showed marked change in both studied tissues. All these biochemical and structural changes were significantly $(P<0.05)$ corrected by LSEO coadministration. More importantly, malathion exposure remarkably $(P<0.05)$ down-regulated the expression of StAR gene as well as, the mRNA levels of P450scc, 3BHSD and 17B-HSD, while LSEO-administration strangely protected against steroidogenesis disruption.
\end{abstract}

Conclusions: The potential protective effects of LSEO against malathion-induced reprotoxicity and oxidative stress might be partially to its antioxidant properties as well as its opposite effect against some gene expression involved in the steroidogenesis.

Keywords: Malathion, Mice, Steroidogenesis, LSEO, Oxidative stress, StAR gene

\footnotetext{
* Correspondence: slimen.selmi@gmail.com

Laboratory Functional Physiology and Bio-resources Valorisation, Higher

Institute of Biotechnology of Beja, University of Jendouba, Avenue Habib

Bourguiba, BP, 382, 9000 Beja, Tunisia
}

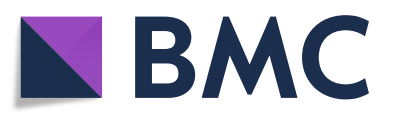

(c) The Author(s). 2018 Open Access This article is distributed under the terms of the Creative Commons Attribution 4.0 International License (http://creativecommons.org/licenses/by/4.0/), which permits unrestricted use, distribution, and reproduction in any medium, provided you give appropriate credit to the original author(s) and the source, provide a link to the Creative Commons license, and indicate if changes were made. The Creative Commons Public Domain Dedication waiver (http://creativecommons.org/publicdomain/zero/1.0/) applies to the data made available in this article, unless otherwise stated. 


\section{Background}

Some organophosphorus (OPs) compounds are known by their effects on impair fertility, suppressif libido, causif testicular degeneration, and deterioration in semen quality [1]. The malathion is an organophosphorus pesticide extensively used as a systemic insecticide and acaricide, which was proved to be neurotoxic and to disturb StAR gene expression $[1,2]$. In fact, in our earlier study, we have shown that continual exposure to malathion decreases testicular weight, serum testosterone level, sperm motility, and increases the percentage of dead and abnormal sperm in male mice [3, 4]. As spermatogenesis and steroidogenesis are dependent upon the maintenance of adequate levels of testosterone and cholesterol, the ability of malathion to reduce their levels may contribute to the reduction of male mice reproductive capability [1]. In fact, several authors have revealed that diazinon inhibit steroidogenesis in the testis [5, 6]. However, various naturally occurring compounds are largely used to protect against reproductive damage and many pathways complications in both the experimental and medical situations. For this reason, the World Health Organization (WHO) has established a program for the use of traditional herbal medicines in the treatment of diverse diseases difficulties and complications [7].

Lavandula stoechas is a well identified medicinal plant species in the word, including Tunisia. However, due to its high content in therapeutically active compounds, this plant presents many beneficial health properties in part due to its antioxidant and anti-inflammatory actions [8]. Recently, it has been demontrated in our laboratory that Lavandula stoechas essential oils (LSEO) have the capacity to reduce blood glycaemic level and protect against oxidative stress induced by alloxan in rats [9]. Additionally, it has been reported that the LSEO supplementation especially protects against the perturbation of lipid metabolic parameters induced by this insecticide intoxication in rats [10].

In our knowledge, the toxicity of malathion on testicular Leydig cell function is still unknowned. Therefore, in the current study we intended to investigate the action of a sub-chronic exposure of male mice to malathion on Leydig cell steroidogenesis, free radicals production as well as StAR, P450 scc, 3 $\beta$-HSD and 17 $\beta$-HSD genes expression. In addition, this study aims also to investigate the protective effect of Lavandula stoechas essential oils (LSEO) against all damages induced by this insecticide as well as the mechanisms involved in this protection.

\section{Methods}

\section{Chemicals}

Malathion (Fyfanon EC 500) was obtained from INNOVA Society size in Tunis, Tunisia at The purity of $96 \%$. 2-Thio-barbituric acid (TBA), bovine catalase, Epinephrine, and butylated hydroxytoluene (BHT) were from Sigma aldrich chemicals Co (Germany). All other chemicals used were of analytical grade.

\section{Plant collection}

The aerial parts of Lavandula stoechas were collected from the area of Ain-Draham (North-West of Tunisia) and identified in laboratory of taxonomy in the Faculty of Sciences of Tunis (FST)-Tunisia. The Voucher specimens (No. L101) have been deposited with the herbarium of the Higher Institute of Biotechnology of Beja, Tunisia.

\section{Plant extracts preparation}

Plant extracts preparation was performed according as describe by Selmi et al. [10].

\section{Gas chromatography-mass spectrometry (GC-MS)}

The essential oils of $L$. stoechas were subjected to GC-MS analysis using Trace GC ULTRA /Polaris Q (GC-MS, Thermo Electron) as described by Sebai et al. with a slight modifications [9].

\section{Animals treatments}

Adult male mice (25-30 g) and were cared for in compliance with the code of practice for the Care and Use of Animals for Scientific Purposes. Approval for these experiments was obtained from the Medical Ethical Committee for the Care and Use of Laboratory Animals of Pasteur Institute of Tunis (approval number: LNFP/Pro 152,012). The experimental protocols were approved by the Faculty Ethics Committee (Faculty of Sciences, Tunis, Tunisia). The animals were housed in standard cages $(40 \times 28 \times 16 \mathrm{~cm})$ under controlled conditions: 12:12-h light:dark, $20-22{ }^{\circ} \mathrm{C}$, food and water are ad libitum. Mice were after divided into 4 groups of 12 animals in each:

Group I (CTR): animals served as control and received equivalent volume of corn oil (1 ml), group II (M): animals were treated with malathion at $200 \mathrm{mg} / \mathrm{kg}$ body weight/day dissolved in $1 \mathrm{ml}$ of corn oil, group III (LSEO): animals received Lavandula stoechas essential oils (50 mg/kg b.w.) and group IV (M + LSEO): animals received both malathion and LSEO under the same conditions.

\section{Body and reproductive organs weights}

Initial (weight at the starting point) and final (weight at the end point) body weights were recorded. Testis and epididymis were stripped from fatty tissues and blood vessels, blotted, and their absolute weights were determined. Clinical signs of body and reproductive organs were evaluated for toxicological criteria. To normalize the data for statistical analysis and to obtain relative weight, data were expressed per $100 \mathrm{~g}$ body weight. 


\section{Testosterone determination}

Serum testosterone level was quantified by enzyme-linked immunosorbent assay (ELISA) using specific commercial kits (DEMEDITEC Diagnostics GmbH, Germany). Data were determined according to the manufacturer's protocols as described by Selmi et al. [3].

\section{Evaluation of sperm characteristics Sperm collection}

Sperm collection was performed as described by Selmi et al. [3]. The sperm count was assessed from right cauda epididymis, whereas sperm motility and morphology were analyzed from the left one.

\section{Sperm count, motility, viability and morphology}

The cauda epididymal sperm count, motility, viability and morphology was performed as described by Selmi et al. [3] according successively to the methods of Vega et al. [11], Kvist and Bjorndahl [12], Tardif et al. [13], WHO [14], Seed et al. [15] and Filler [16].

\section{Steroidogenesis gene expression analysis}

RNA extraction and RT-PCR Total RNA from rat testis was isolated with RNeasy Mini Kit (ambion by Life Technology) according to the manufacturer's protocol as described by Selmi et al. [3]. The relative mRNA abundance was calculated by the ratio of sample-to-control.

\section{Oxidative stress biomarkers}

\section{Lipid peroxidation and $\mathrm{H} 2 \mathrm{O} 2$ generation}

Lipid peroxidation was detected by the determination of MDA content as described by the method of Buege and Aust [17] with a slight modification. MDA levels were determined by using an extinction coefficient for MDATBA complex of $1.5610^{5} \mathrm{M}^{-1} \mathrm{~cm}^{-1}$ and expressed as $\mathrm{nmol} / \mathrm{mg}$ protein. Hydrogen peroxide content in both reproductive-organs was performed according to Dingeon et al. [18] and the results were expressed as $\mu \mathrm{mol}$ of $\mathrm{H}_{2} \mathrm{O}_{2}$ per mg of protein.

\section{Thiol groups measurement}

Total Thiol groups concentration (-SH) was performed according to Ellman method with slight modifications [19]. Results were expressed as nmol of thiol groups per mg of protein.

\section{Antioxidant activities assays}

Determination of SOD activity was performed according of Misra and Fridovich with slight modifications [20]. Characterization of SOD isoforms was performed using $\mathrm{KCN}(2 \mathrm{mM})$, which inhibits $\mathrm{Cu} / \mathrm{Zn}-\mathrm{SOD}$ or $\mathrm{H}_{2} \mathrm{O}_{2}$ ( $5 \mathrm{mM}$ ), affecting both $\mathrm{Cu} / \mathrm{Zn}-\mathrm{SOD}$ and Fe-SOD whereas Mn-SOD was insensitive to both inhibitors [21].
Table 1 L. stoechas essential-oil phytochemical composition identified using a GC-MS analyze

\begin{tabular}{|c|c|c|c|}
\hline No & Components & IR & Compositions (\%) \\
\hline 1 & Tricyclene & 6.137 & 0.51 \\
\hline 2 & a-pinene & 6.720 & 23.18 \\
\hline 3 & Camphene & 7.310 & 7.83 \\
\hline 4 & $\beta$-Phellandrene & 8.500 & 0.10 \\
\hline 5 & $\beta$-Pinene & 8.626 & 0.12 \\
\hline 6 & Delta 3-Carene & 10.554 & 0.11 \\
\hline 7 & Cymene & 11.504 & 0.72 \\
\hline 8 & Limonene & 11.807 & 2.71 \\
\hline 9 & Eucapur & 11.893 & 3.29 \\
\hline 10 & D-Fenchone & 15.835 & 29.28 \\
\hline 11 & Linalool & 16.785 & 2.01 \\
\hline 12 & Camphor & 19.526 & 15.97 \\
\hline 13 & Myrtenol & 23.228 & 0.26 \\
\hline 14 & Endobornyl Acetate & 29.122 & 1.03 \\
\hline 15 & Aromad Endrene & 33.991 & 0.28 \\
\hline 16 & a-Copaene & 34.809 & 0.28 \\
\hline 17 & Caryophyllene & 37.436 & 0.26 \\
\hline 18 & $\beta$-Selinene & 41.533 & 0.26 \\
\hline 19 & Delta-Cadinene & 43.953 & 0.67 \\
\hline 20 & a -Elemene & 44.434 & 0.12 \\
\hline 21 & Selina-3,7(11)-diene & 44.817 & 0.85 \\
\hline 22 & Delta-gurjunene & 47.730 & 0.20 \\
\hline
\end{tabular}

IR Retention Index

CAT activity was assayed according to Aebi with slight modifications [22]. CAT activity calculated using the extinction coefficient of $40 \mathrm{mM}^{-1} \mathrm{~cm}^{-1}$ for $\mathrm{H}_{2} \mathrm{O}_{2}$.

GPx activity was determined according to Flohé and Günzler [23]. GPx activity was expressed as nmol of $\mathrm{GSH}$ consumed $/ \mathrm{min} / \mathrm{mg}$ protein.

Table 2 Effect of sub-chronic treatment (30 days) malathion (200 mg / kg BW, po) and / or essential oils of lavender (50 mg / kg, PC, OP) on relative weight of testis and epididymis in male mice

\begin{tabular}{lllll}
\hline Parameters & CTR & $M$ & LSEO & $M+$ LSEO \\
\hline $\begin{array}{l}\text { Testis relative } \\
\text { weight }\end{array}$ & $0.52 \pm 0.01$ & $0.63 \pm 0.06^{*}$ & $0.54 \pm 0.04^{\#}$ & $0.49 \pm 0.02^{\#}$ \\
( $/ 100 \mathrm{~g}$ b.w) & & & & \\
$\begin{array}{l}\text { Epididymis relative } \\
\text { weight }\end{array}$ & $0.09 \pm 0.01$ & $0.12 \pm 0.02^{*}$ & $0.09 \pm 0.02^{\#}$ & $0.1 \pm 0.02^{\#}$ \\
(g/100 g b.w) & & & & \\
\hline
\end{tabular}

The results represent the mean \pm SEM $(n=12)$. ( ${ }^{*} P<0.05$ vs. control, and \#: $P<0.05$ vs malathion-group by the student-test) 


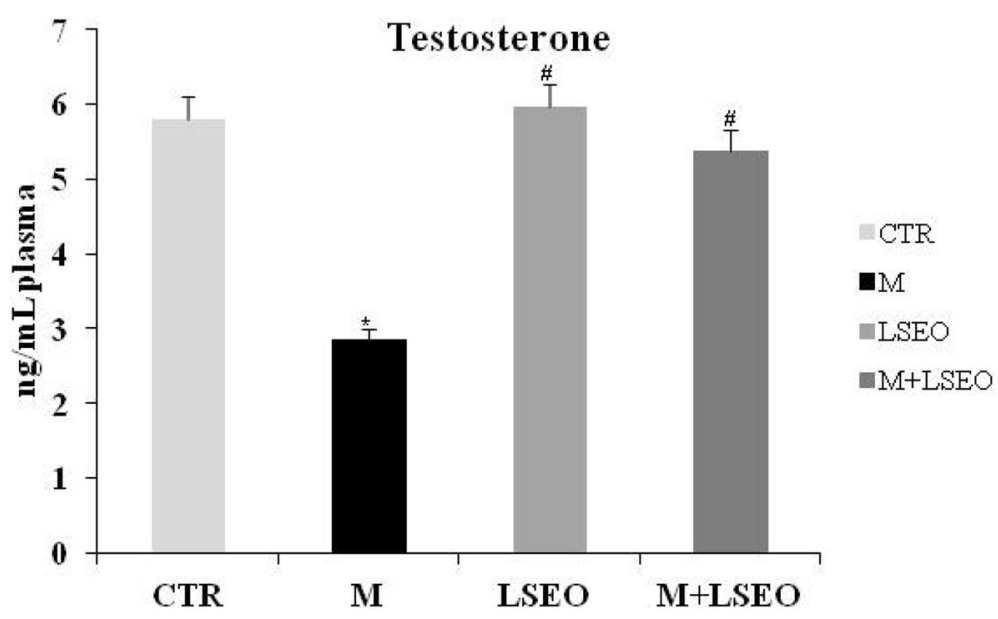

Fig. 1 Subchronic effect (30 days) of malathion (200 mg / kg BW, po) and / or lavender essential oils (LSEO) (50 mg / kg, PC, OP) on testosterone levels in male mice. Values are expressed as mean $\pm \operatorname{SEM}(n=12)$. ${ }^{*}$ Comparison of CTR and other groups $\left(p\right.$ 0.05). ${ }^{*}$ Comparison of $\mathbf{M}$ with $\mathbf{L S E O}$ group ( 0.05$)$

\section{Protein determination}

Protein content in the testis and epididymis was determined by the method of Bradford using bovine serum albumin (BSA) as standard [24].

\section{Histopathological examination}

Histopathological examination in testis and epididymis tissues was performed by the method described by Selmi et al. [3].

\section{Statistical analysis}

The data were analyzed by unpaired $t$-student test and were expressed as means \pm standard error of the mean (S.E.M.). The data are representative of 12 independent experiments. All statistical tests were two-tailed, and a $p$ value of 0.05 or less was considered significant.

\section{Results}

\section{Chemical composition of the lavender essential oils}

L. stoechas essential-oil bioactive-compounds were identified by the GC-MS technique and presented in Table 1. In this respect, thirty-two compounds have been identified. The main components are: D-Fenchone (29.28\%), $\alpha$-pinene (23.18\%) and camphor (15.97\%). These cyclic compounds belong essentially to the family of oxygenated monoterpenes known for their antioxidant and free radical scavengers.

\section{Testis and epididymis relative weights}

Data from Table 2, showed that sub-chronic exposure of male mice to malathion-induced a significant decrease $(P<0.05)$ of testis/epididymis relative-weights. Indeed, these last were reduced from $0.52 \pm 0.01$ to $0.63 \pm 0.06$ and from $0.09 \pm 0.01$ to $0.12 \pm 0.02$ in malathion-treated-group respectively. However, LSEO pre-treatment significantly
$(P<0.05)$ protected against malathion-caused reproductive organs weight loss.

\section{Testosterone determination}

Data from Fig. 1, showed that sub-chronic exposure of male mice to malathion-induced a significant diminution $(P<0.05)$ of serum testosterone level in all treated-groups. In contrast, the Co-administration of malathion and LSEO had no effect on the testosterone level.

Table 3 Effect of sub-chronic treatment (30 days) malathion (200 mg / kg BW, po) and / or essential oils of lavender (50 mg $/ \mathrm{kg}, \mathrm{PC}, \mathrm{OP}$ ) on variation in the sperm parameters in male-mice

\begin{tabular}{|c|c|c|c|c|}
\hline Parameters & $C T R$ & $M$ & LSEO & $M+$ LSEO \\
\hline $\begin{array}{l}\text { Sperm } \\
\text { concentration } \\
\left(10^{6} / \mathrm{mL}\right)\end{array}$ & $7.36 \pm 2.00$ & $2.76 \pm 1.00^{*}$ & $7.89 \pm 1.00^{\#}$ & $7.21 \pm 2.00^{\#}$ \\
\hline Motility (\%) & $69.00 \pm 7.00$ & $40.00 \pm 5.00^{*}$ & $68.00 \pm 4.00^{\#}$ & $67.00 \pm 5.00^{\#}$ \\
\hline Viability (\%) & $79.00 \pm 4.00$ & $22.00 \pm 6.00^{*}$ & $81.00 \pm 4.00^{\#}$ & $72.00 \pm 5.00^{\#}$ \\
\hline $\begin{array}{l}\text { Morphology } \\
\text { (normal form) (\%) }\end{array}$ & $86.10 \pm 4.52$ & $46.00 \pm 3.00^{*}$ & $89.00 \pm 4.56^{\#}$ & $79.00 \pm 5.38^{*}$ \\
\hline $\begin{array}{l}\text { Head } \\
\text { Abnormal } \\
\text { sperm (\%) }\end{array}$ & $5.80 \pm 0.96$ & $14.00 \pm 2.10^{*}$ & $4.62 \pm 1.12^{\#}$ & $6.49 \pm 1.71^{\#}$ \\
\hline $\begin{array}{l}\text { Caudal } \\
\text { Abnormal } \\
\text { sperm (\%) }\end{array}$ & $8.10 \pm 1.41$ & $39.00 \pm 4.20^{*}$ & $11.60 \pm 2.30^{\#}$ & $15.80 \pm 1.90^{\#}$ \\
\hline $\begin{array}{l}\text { Sperm } \\
\text { count } 10^{6} / \mathrm{g} \\
\text { epididymis }\end{array}$ & $132.00 \pm 16.40$ & $96.00 \pm 1.98^{*}$ & $134.00 \pm 1.96^{\#}$ & $123.00 \pm 3.49^{\#}$ \\
\hline $\begin{array}{l}\text { Spermatid } \\
\text { count } 10^{6} / \mathrm{g} \\
\text { of testis }\end{array}$ & $200.00 \pm 9.30$ & $118.00 \pm 5.89^{*}$ & $189.00 \pm 7.21^{\#}$ & $183.00 \pm 8.78^{\#}$ \\
\hline
\end{tabular}

The results represent the mean \pm SEM $(n=12) .\left(^{*}: P<0.05\right.$ vs. control, and \#: $P$ $<0.05$ vs Malathion by the student t-test) 


\section{Evaluation of reproductive performance quality}

Data from Table 3, showed that 30 days exposure to malathion-provoked a significant depletion $(P<0.05)$ of different sperm parameters such as epididymal sperm concentration $\left(7.36 \pm 2.00\right.$ to $\left.2.76 \pm 1.0010^{6} / \mathrm{mL}\right)$, motility $(69.00 \pm 7.00 \%$ to $40.00 \pm 5.00 \%)$, viability $(79.00 \pm 4.00 \%$ to $22.00 \pm 6.00 \%$ ), sperm count (132.00 \pm 16.40 to $96.00 \pm$ $1.9810^{6} / \mathrm{g}$ epididymis) and testicular spermatids count $(200.00 \pm 9.30$ to $118.00 \pm 5.89$ ), while, the number of dead sperm increased remarkably $(P<0.05)$ (Table 3$)$. Added to that, malathion-produced a significant decrease of viability, thiols-groups and DNA-decompaction as assessed by flow cytometry using monobromobimane (MB), propidium iodide (PI), chromomycine A3 (CMA3) as a probe (Figs. 2, 3 and 4).

Morphological abnormalities of spermatozoa were evaluated based on head or tail forms. LSEO co-administration $(50 \mathrm{mg} / \mathrm{kg})$ to male mice intoxicated with malathion at a dose of $200 \mathrm{mg} / \mathrm{kg}$ leads to a restoration of all male-fertility-parameters and reduce abnormal spermatozoa forms and the results were comparable to those experimental in the normal-animals.

\section{Steroidogenesis gene expression analysis}

We further looked at the effect of malathion $(200 \mathrm{mg} \mathrm{kg}$, b.w.) exposure during 30 days on StAR protein gene-expression responsible for cholesterol transport as well as steroidogenic enzymes P450scc, 3ßHSD, and 17ß-HSD. The expression levels were normalized by $\beta$-actin expression detected in the same PCR reaction, and these values were compared with those of the control group. As expected, there was no change in the expression of $\beta$-actin in control and treated groups. However, malathion exposure caused a singnificant-decrease $(P<0.05)$ in both StAR, P450scc, $3 ß \mathrm{HSD}$, and $17 ß-\mathrm{HSD}$ when compared to control group. In opposite, LSEO co-administration of had no effect on steroidogenesis gene expression (Table 4 and Fig. 5).

A

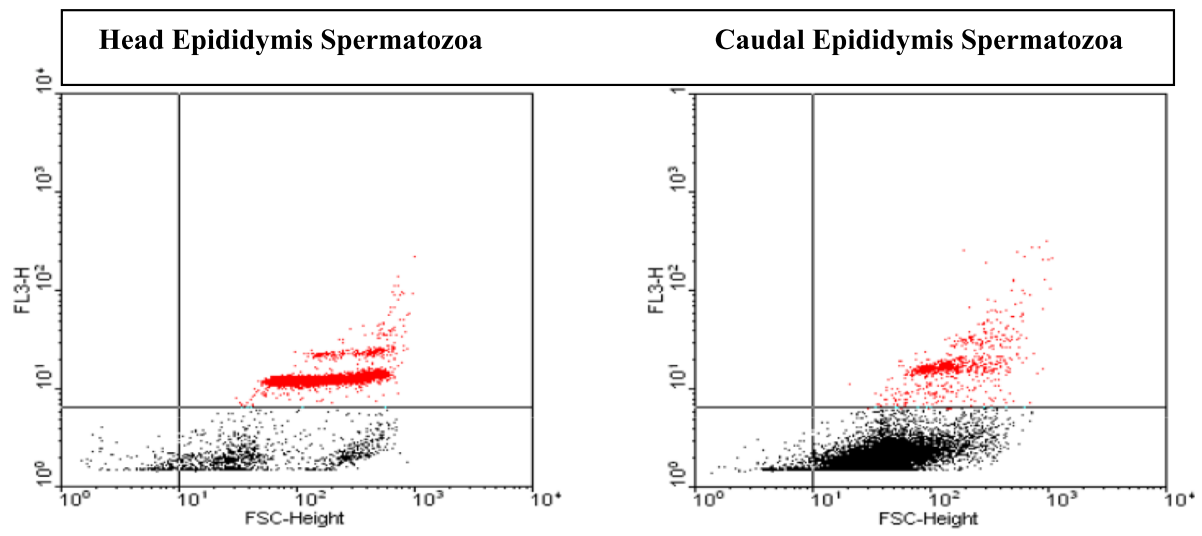

B

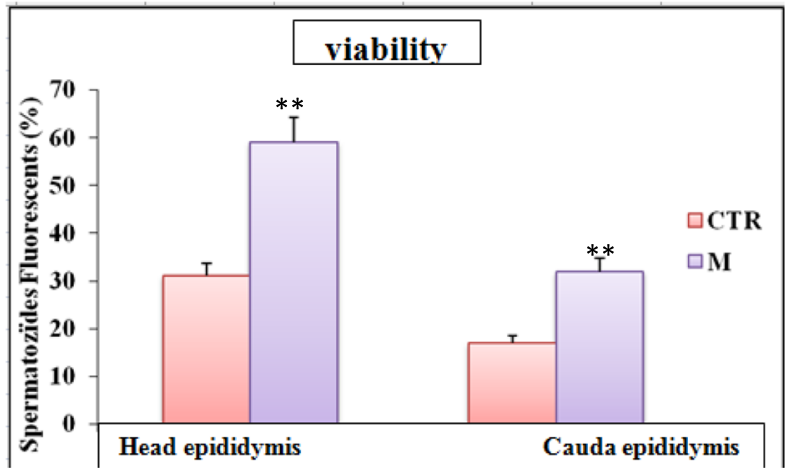

Fig. 2 Determination of sperm viability by flow cytometry using propidium iodide (PI) as a probe. a Chart type obtained with the cytometer shows the dispersion of the cells according to their fluorescence (FL3) and size (FSC). The fluorescence threshold is indicated, the red dots placed above this threshold represent the fluorescent cells. $\mathbf{b}$ The percentage of fluorescent sperm is then determined by the software and averages are calculated is presented as a histogram $(n=6) .{ }^{* *} P<0.01$ Control vs Malathion 
A

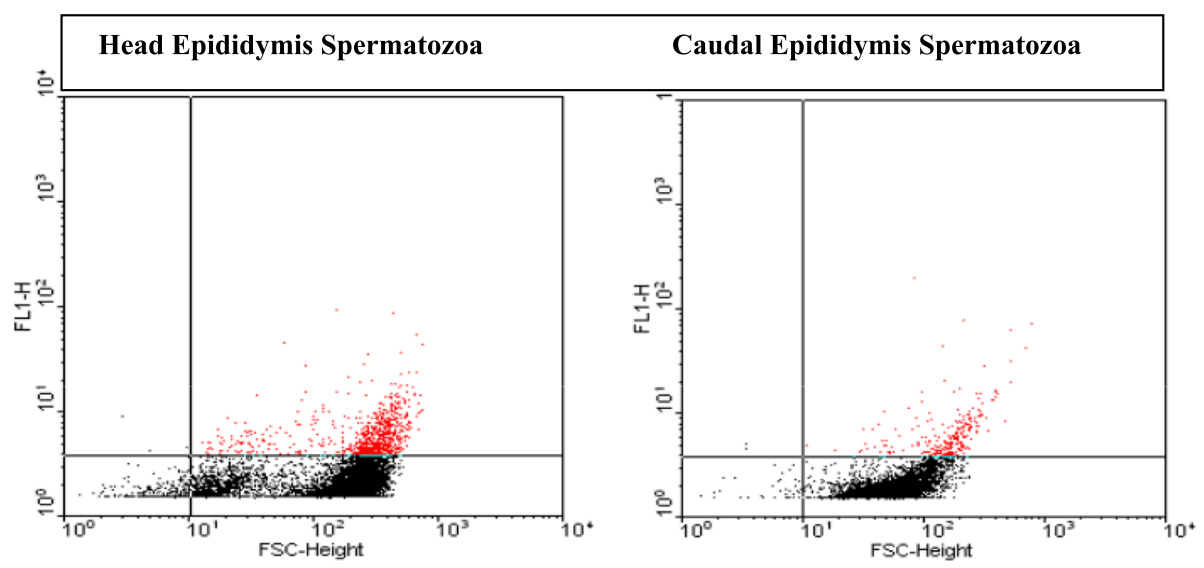

B

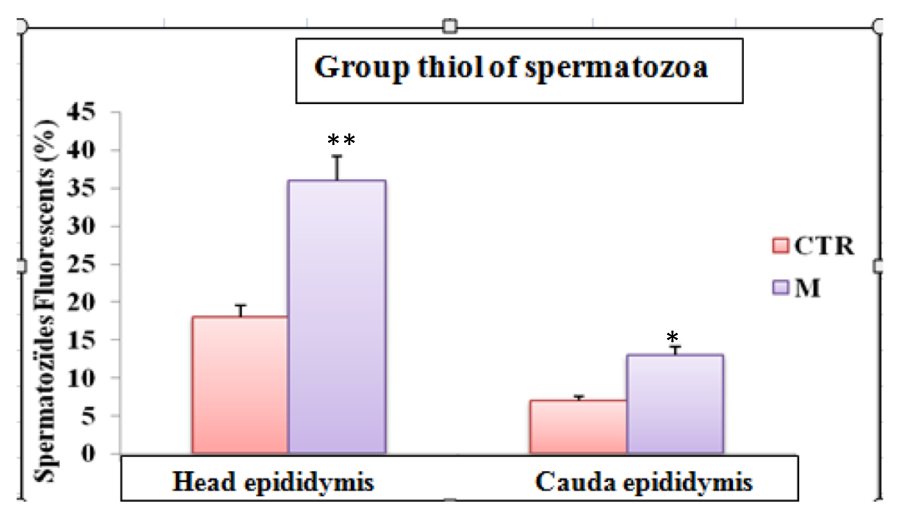

Fig. 3 Determination of spermatic thiols groups by flow cytometry using monobromobimane (MB) as a probe. a Chart type obtained with the cytometer shows the dispersion of the cells according to their fluorescence (FL3) and size (FSC). The fluorescence threshold is indicated, the red dots placed above this threshold represent the fluorescent cells. $\mathbf{b}$ The percentage of fluorescent sperm is then determined by the software and averages are calculated is presented as a histogram $(n=6) .{ }^{*} P<0.01$ Control vs Malathion

\section{Oxidative stress biomarkers and antioxidants enzymes activities}

To assess the effect of the organophosphorus compound and essential-oils on oxidative stress situation, the some antioxidant biomarkers were evaluated in the different groups. Results showed that oxidative-stress induced by malathion-treatment is explained by a significant increase $(P<0.05)$ of lipoperoxydation in testis and epididymis, hydrogen peroxide production $(P<0.05)$ as well as a decrease $(P<0.05)$ of thiol groups content (Tables 5, 6 and 7). However, the treatment of animals with LSEO protects against all these alterations caused by malathion-intoxication. On another hand, we examined the antioxidant-enzyme-activities in testis and epididymis (Tables 8, 9, 10 and 11). As expected, malathion-intoxication induced a significantly $(P<0.05)$ reduce of CAT, GPx, total SOD and SOD isoforms such as $\mathrm{Cu} / \mathrm{Zn}-\mathrm{SOD}$ and $\mathrm{Mn}$-SOD activities. The sub-chronic co-administration of LSEO markedly $(\mathrm{P}<0.05)$ protected against the depletion of testis/epididymis antioxidant enzyme activities induced by malathion exposure during 30 days.

\section{Histopathological examination}

Histological organization of the testis is illustrated in Fig. 6. Testis of undamaged control (Fig. 6a) showed regular seminiferous tubules lined with germinal epithelial layer. Different types of spermatogenic, cells appeared in their ordinary form with: spermatogonia, primary and secondary spermatocytes, spermatids and mature spermatozoa. Sertoli and Leydig cells with standard form were observed. Leydig cells and blood vessels were found in the interstitial connective tissues between the seminiferous tubules, and the tubules which appeared with regular size and shape. 
A

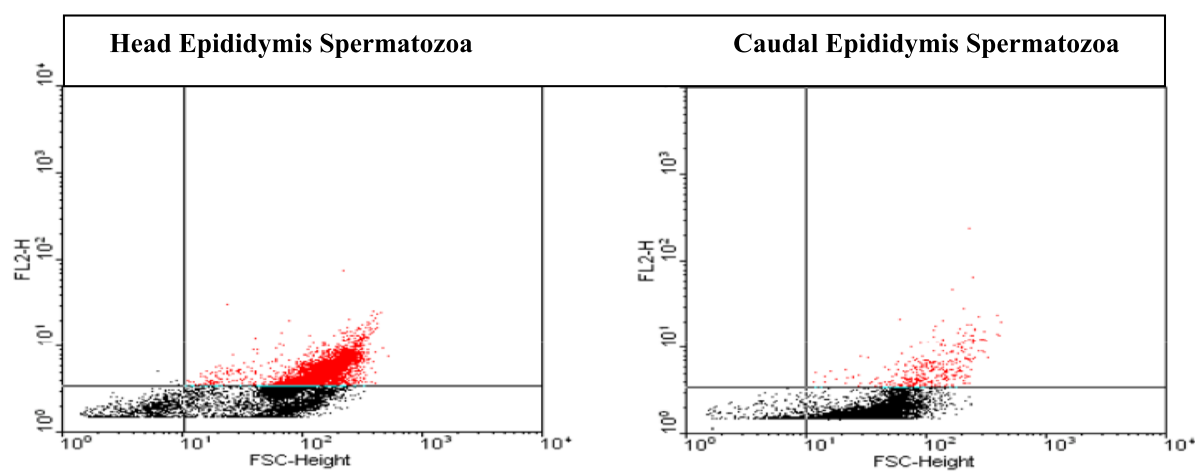

B

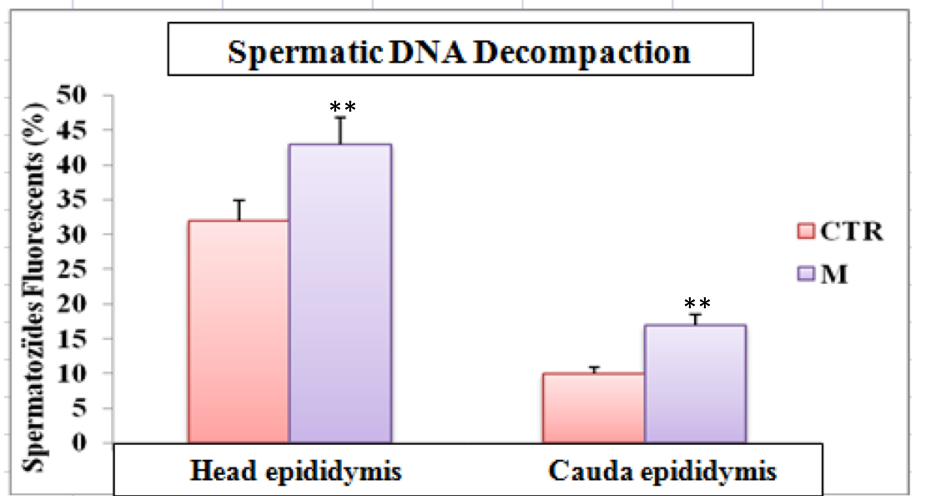

Fig. 4 Determination of spermatic DNA decompaction by flow cytometry using chromomycine A3 (CMA3) as a probe. a Chart type obtained with the cytometer shows the dispersion of the cells according to their fluorescence (FL3) and size (FSC). The fluorescence threshold is indicated, the red dots placed above this threshold represent the fluorescent cells. $\mathbf{b}$ The percentage of fluorescent sperm is then determined by the software and averages are calculated is presented as a histogram $(n=6) .{ }^{* *} P<0.01$ Control vs Malathion

Malathion exposure (Fig. 6b) caused necrosis, deterioration, diminishing the number of spermatogenic cells in seminiferous tubules, unscrambling of cells from basal region of seminiferous tubules and loss the Leydig cells in interstitial tissue. LSEO Co-administrated to malathion protected and recovered the damages of testicular tissues,

Table 4 Primers used for RT-PCR

\begin{tabular}{lll}
\hline Primer & Primer Sequence $\left(5^{\prime}\right.$-3 $\left.{ }^{\prime}\right)$ & $\operatorname{Tm}\left({ }^{\circ} \mathrm{C}\right)$ \\
\hline StAR & $\begin{array}{l}\text { Forward: GCCCCGAGACTTCGTAAG } \\
\text { Reverse: CAGGTGGGCCGTGTCA }\end{array}$ & $\mathbf{5 9}$ \\
P450scC & $\begin{array}{l}\text { Forward: GCCCCGAGACTTCGTAAG } \\
\text { Reverse: CAGGTGGGACCGTGTTCA }\end{array}$ & $\mathbf{6 0}$ \\
$3 \beta-H S D$ & $\begin{array}{l}\text { Forward: CCTGCTGCGTCCATTTA } \\
\text { Reverse: TCTGCTTGGCTCCTCCC }\end{array}$ & $\mathbf{6 0}$ \\
$17 \beta-H S D$ & Forward: ACCGCCGATGAGTTGTT & $\mathbf{6 0}$ \\
B-Actin & Reverse: GGGTGGTGTGCTGTAGA & \\
& Forward: GAGATTACTGCCCTGGCTCCTA & $\mathbf{6 0}$ \\
\hline
\end{tabular}

induced by the malathion intoxication. On the other hand, concerning the histomorphology of epididymis, we showed that malathion exposure caused a loss of sperm from the lumen of epididymis as well as the disintegration of basal membrane (Fig. 7b), whereas the co-treatment with LSEO restored the architecture of epididymis as evidenced by the accumulation of sperm in the centre of lumen and the regeneration of lining cells (Fig. 7c and d).

\section{Discussion}

Firstly, the chemical analysis using GC-MS technique allowed to the identification of 22 compounds. In vivo part study, we showed that the subchronic-exposure to malathion leads to a significant decline of testis/epididymis relative weights indicating a testicular deterioration. Added to that, our results showed a marked decrease in serum testosterone levels in male mice after chemical intoxication. These alterations were accompanied with a concomitant decrease in the mRNA level of the genes 


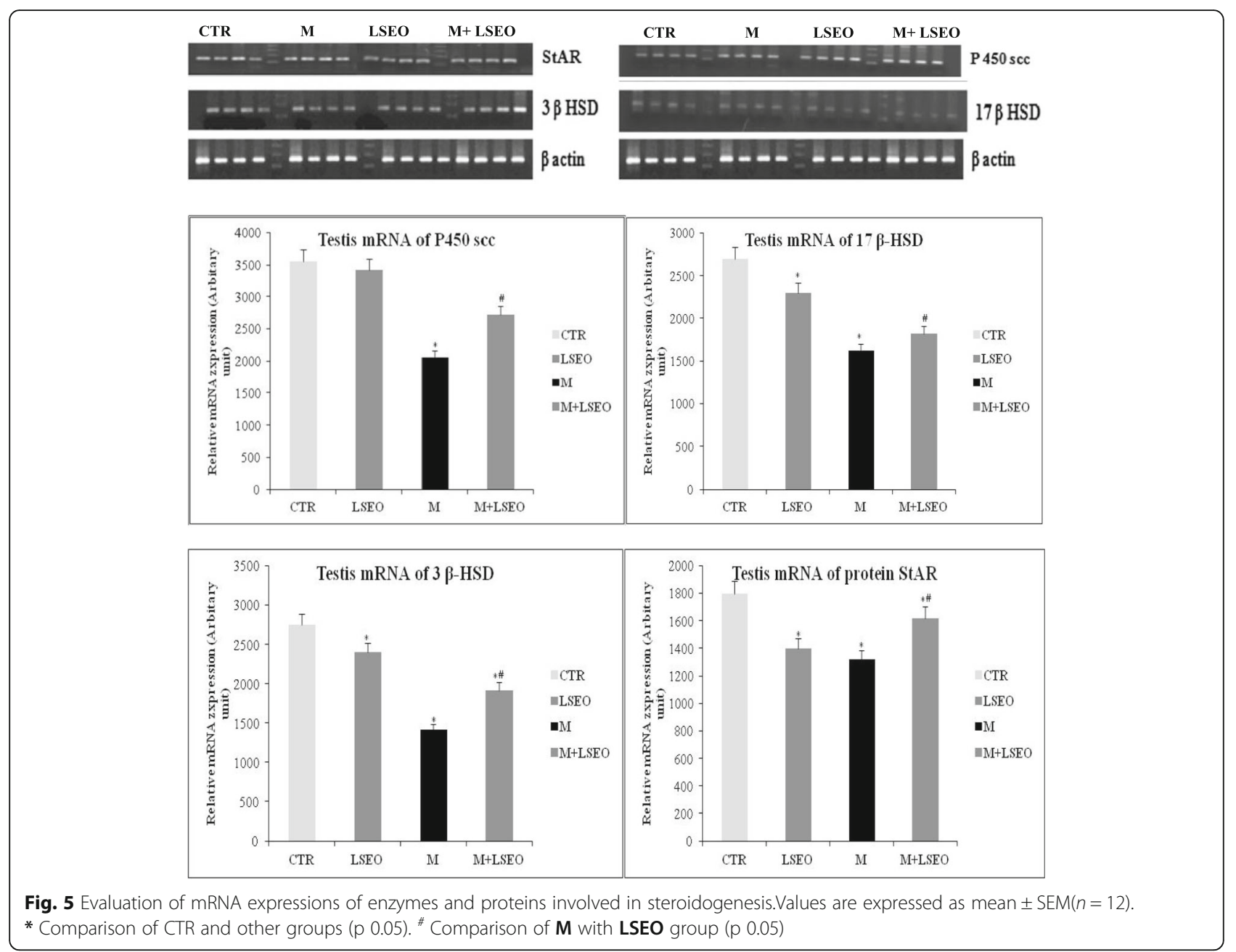

involved in the transport and transfer of cholesterol and steroidogenesis, including that of the StAR protein, P450scc, 3 $\beta$-HSD and 17 $\beta$-HSD, was observed in contrast to an increase in the total cholesterol level of the same group. More importantly, we showed in this study, a significative-diminution in mRNA expression of StAR, P450scc, 3ßHSD, and 17ß-HSD was detected after malathion-exposure, while, LSEO co-administration extensively ameliorated the mRNA expression of studied

Table 5 Effect of sub-chronic treatment (30 days) malathion (200 mg / kg BW, po) and / or essential oils of lavender (50 mg / kg, PC, OP) on variation of MDA levels on testis and epididymis of male mice

\begin{tabular}{lllll}
\hline MDA (nmol/mg protein) & & & \\
\hline & CTR & $M$ & LSEO & $M+$ LSEO \\
Testis & $3.80 \pm 0.37$ & $6.20 \pm 0.35^{*}$ & $3.60 \pm 0.34$ & $4.10 \pm 0.22^{\#}$ \\
Epididymis & $3.20 \pm 0.28$ & $5.30 \pm 0.46^{*}$ & $3.20 \pm 0.14^{\#}$ & $3.50 \pm 0.18^{\#}$
\end{tabular}

The results represent the mean \pm SEM $(n=12) .\left(^{*}: P<0.05\right.$ vs. control, and $\#: p<0.05$ vs Malathion by the student $\mathrm{t}$-test) genes. We also studied the effect of coadministration of malathion and LSEO on oxidative stress parameters. In this context, we showed that malathion-administration induced oxidative stress as assessed by an increase of lipid peroxidation and hydrogen peroxide level, a decrease of sulfhydrils content, as well as a depletion of antioxidant enzyme activities such as CAT, GPx, total SOD, Cu/Zn-SOD, Mn-SOD, and Fe-SOD in testis and epididymis. All these alterations

Table 6 Effect of a sub-chronic treatment (30 days) by malathion (200 mg / kg BW, po) and / or essential oils of lavender (50 mg / $\mathrm{kg}, \mathrm{PC}, \mathrm{OP}$ ) on thiols groups level of the testis and epididymis in male mice

\begin{tabular}{lllll}
\hline -SH (nmol/mg of protein) & & & \\
\hline & CTR & $M$ & LSEO & $M+$ LSEO \\
\hline Testis & $0.89 \pm 0.04$ & $0.58 \pm 0.03^{*}$ & $0.87 \pm 0.04^{\#}$ & $0.76 \pm 0.03^{\#}$ \\
Epididymis & $0.36 \pm 0.02$ & $0.26 \pm 0.02^{*}$ & $0.37 \pm 0.02^{\#}$ & $0.37 \pm 0.02^{\#}$
\end{tabular}

The results represent the mean $\pm \operatorname{SEM}(n=12) .\left(^{*}: P<0.05\right.$ vs. control, and $\#: p<0.05$ vs Malathion by the student $\mathrm{t}$-test) 
Table 7 Effect of sub-chronic treatment (30 days) malathion (200 mg / kg BW, po) and / or essential oils of lavender (50 mg / kg, PC, OP) on variation of the rate of hydrogen peroxide $\left(\mathrm{H}_{2} \mathrm{O}_{2}\right)$ in testis and epididymis in male mice

\begin{tabular}{lllll}
\hline $\mathrm{H}_{2} \mathrm{O}_{2}$ ( $\mu \mathrm{mol} / \mathrm{mg}$ proteins) & & & \\
\hline & $\mathrm{CTR}$ & $\mathrm{M}$ & LSEO & $\mathrm{M}+\mathrm{LSEO}$ \\
\hline Testis & $0.84 \pm 0.07$ & $1.78 \pm 0.06^{*}$ & $0.88 \pm 0.08^{\#}$ & $0.96 \pm 0.06^{\#}$ \\
Epididymis & $0.69 \pm 0.06$ & $1.23 \pm 0.05^{*}$ & $0.63 \pm 0.06^{\#}$ & $0.89 \pm 0.02^{* *}$ \\
\hline
\end{tabular}

The results represent the mean \pm SEM $(n=12)$. ${ }^{*}: P<0.05$ vs. control,

and \#: $p<0.05$ vs Malathion by the student t-test)

were associated with histopathological changes in both reproductive-organs.

Testis weight is principally dependent on the mass of the differentiated spermatogenic cells; the lessening in its weight may be due to decreased number of germ cells, inhibition of spermatogenesis, and steroidogenesis $[25,26]$. This loss of weight may also be due to a reduction in the bioavailability of testosterone, $\mathrm{LH}$ and FSH, whose levels in the bloodstream indicate the reproductive endocrine status of the male [27]. We also found that LSEO treatment significantly attenuated the effect of malathion on testicular weight. However, LSEO is known for its potential for tissue chelation and supplementation during malathion poisoning, and reduces the level of pesticide and its active metabolites in testicular tissue.

Since testicular Leydig cells are the site of synthesis of male steroid hormone. This hormone also plays a key role in the conservation of male sexual characteristics, spermatogenesis and fertility [28]. Our results are in agreement with our previous work, which found that a low serum testosterone concentration in rats may be due to the inhibition of the activities of steroidogenic enzymes [3], which are responsible for regulating the biosynthesis of testosterone, or because of the deleterious effects caused by malathion on Leydig cells through the generation of ROS $[29,30]$. Importantly, we showed in this study that LSEO co-administration stimulated the testosterone biosynthesis. This beneficial effect on testosterone defence

Table 8 Effect of sub-chronic treatment (30 days) malathion (200 mg / kg BW, po) and / or essential oils of lavender (50 mg / kg, PC, OP) on catalase (CAT) activity of levels in testis and epididymis in mice

\begin{tabular}{lllll}
\hline \multicolumn{5}{l}{ Catalase $\left(\mathrm{nmol} \mathrm{min} \mathrm{mg}^{-1} \mathrm{mg}^{-1}\right.$ proteins) } \\
\hline Testis & CTR & M & LSEO & $\mathrm{M}+$ LSEO \\
& $563.00 \pm$ & $246.00 \pm$ & $578.00 \pm$ & $594.00 \pm$ \\
Epididymis & $193.00 \pm$ & $23.90^{*}$ & $28.50^{* \#}$ & $36.20^{\#}$ \\
& 19.80 & $98.00 \pm$ & $196.00 \pm$ & $162.00 \pm$ \\
& $17.60^{*}$ & $25.40^{\#}$ & $22.70^{* \#}$ \\
\hline
\end{tabular}

The results represent the mean \pm SEM $(n=12)$. (*: $P<0.05$ vs. control, and \#: $p<0.05$ vs Malathion by the student t-test)
Table 9 Effect of sub-chronic treatment (30 days) malathion (200 mg / kg BW, po) and / or essential oils of lavender (50 mg / kg, PC, OP) on glutathione peroxidase (GPx) activity of testis and epididymis in mice

GPx (GSH consumed/min/mg protein)

\begin{tabular}{lllll}
\hline & CTR & $M$ & LSEO & $M+$ LSEO \\
\hline Testis & $9.20 \pm 0.90$ & $4.70 \pm 0.5^{\circ *}$ & $9.60 \pm 0.45^{\#}$ & $8.20 \pm 0.47^{\#}$ \\
Epididymis & $7.50 \pm 0.50$ & $3.30 \pm 0.60^{*}$ & $7.70 \pm 0.20^{\#}$ & $6.70 \pm 0.42^{\#}$ \\
\hline
\end{tabular}

The results represent the mean $\pm \operatorname{SEM}(n=12)$. ( ${ }^{*}: P<0.05$ vs. control,

and \#: $p<0.05$ vs Malathion by the student t-test)

might be in part due to the protection of Leydig cells beside malathion intoxication by LSEO [31].

However, the conversion of cholesterol to testosterone in Leydig cells, the cholesterol is done in several stages and is under the action of different enzymes for each [32]. The free cholesterol tranfer of the extacellular and intracellular medium to the internal mitochondrial membrane is Limiting stage of steroidogenesis and it is mainly mediated by acute steroids-regulators. (StAR) $[32,33]$. The physiological action of this protein depends on many internal factors such as PGF levels, COX-2 activity and exogenous factors by the overproduction of free radicals in a complex relationship still poorly understood [34-37]. StAR is also susceptible to a variety of pesticides as confirmed by Walsh et al. [2]. Steroidogenesis involves numerous steps in the synthesis of cholesterol to its transport within steroidogenic tissues and then its metabolism to steroids. Under normal physiological conditions, the collection of cholesterol by steroidogenic cells from free cholesterol circulating in the blood and high density / low density lipoprotein (HDL / LDL). In our previous studies, the administration of malathion at $200 \mathrm{mg} / \mathrm{kg} /$ day caused an imbalance in metabolic parameters marked by decreased plasma HDL cholesterol with elevated cholesterol, triglyceride and VLDL-CL levels [10]. Furthermore, malathion causes a decrease in the transport and use of cholesterol for steroidogenesis which explains this dyslipidemia. In addition, Barlow et al., [38] established that decreased cholesterol synthesis

Table 10 Effect of sub-chronic treatment (30 days) malathion (200 mg / kg BW, po) and / or essential oils of lavender (50 mg / $\mathrm{kg}, \mathrm{PC}, \mathrm{OP}$ ) on variation in the activity of superoxide dismutase (SOD) total ( $U$ of SOD activity per mg proteins), Cu / Zn SOD, $\mathrm{Mn}-\mathrm{SOD}$ and Fe-SOD in the testes in mice

\begin{tabular}{lllll}
\hline Testis SOD & CTR & $M$ & LSEO & $M+$ LSEO \\
\hline SOD Total & $8.34 \pm 0.67$ & $4.48 \pm 0.42^{*}$ & $8.43 \pm 0.38^{\#}$ & $6.89 \pm 0.51^{* \#}$ \\
Cu/zn-SOD & $4.36 \pm 0.45$ & $2.23 \pm 0.24^{*}$ & $4.97 \pm 0.41^{\#}$ & $4.09 \pm 0.3^{\#}$ \\
Mn-SOD & $2.49 \pm 0.36$ & $1.47 \pm 0.15^{*}$ & $2.56 \pm 0.13^{\#}$ & $1.63 \pm 0.27^{*}$ \\
Fe-SOD & $1.14 \pm 0.13$ & $1.09 \pm 0.18$ & $1.16 \pm 0.22$ & $1.18 \pm 0.12$
\end{tabular}

The results represent the mean \pm SEM $(n=12) .\left({ }^{*}: P<0.05\right.$ vs. control, and \#: $p<0.05$ vs Malathion by the student t-test) 
Table 11 Effect of sub-chronic treatment (30 days) malathion (200 mg / kg BW, po) and / or essential oils of lavender (50 mg / $\mathrm{kg}, \mathrm{PC}, \mathrm{OP}$ ) on variation in the activity of superoxide dismutase (SOD) total ( $U$ of SOD activity per mg proteins), Cu / Zn SOD, $\mathrm{Mn}-\mathrm{SOD}$ and Fe-SOD in the epididymis in mice

\begin{tabular}{lllll}
\hline Epididymis SOD & CTR & $M$ & LSEO & $M+$ LSEO \\
\hline SOD Total & $6.67 \pm 0.47$ & $3.56 \pm 0.28^{*}$ & $6.63 \pm 0.38^{\#}$ & $6.29 \pm 0.51^{\#}$ \\
Cu/zn-SOD & $3.91 \pm 0.22$ & $1.21 \pm 0.22^{*}$ & $3.64 \pm 0.23^{\#}$ & $3.82 \pm 0.12^{\#}$ \\
Mn-SOD & $1.62 \pm 0.16$ & $1.42 \pm 0.21^{*}$ & $1.66 \pm 0.11^{\#}$ & $1.69 \pm 0.09^{\#}$ \\
Fe-SOD & $0.78 \pm 0.07$ & $0.71 \pm 0.05$ & $0.74 \pm 0.06$ & $0.76 \pm 0.04$ \\
\hline
\end{tabular}

The results represent the mean \pm SEM $(n=12) .(*: P<0.05$ vs. control, and \#: $p<0.05$ vs Malathion by the student t-test)

results in the downregulation of steroidogenesis. On the other hand, the subchronic LSEO co-administration considerably improves dyslipidemia induced by malathion in male mice. In addition, the rate of these parameters has been returned to near normal.

The decrease in mRNA expression of StAR, P450scc, $3 ß \mathrm{HSD}$, and $17 ß-\mathrm{HSD}$ are previously shown to be responsible for cholesterol transport and testosterone synthesis in mice and rat testis [39]. In accordance with our results, Walsh et al. [2] demonstrated that dimethoate can inhibit steroidogenesis by blocking transcription of the StAR gene in MA-10 Leydig mouse tumor cells, thereby highlighting the sensitivity of StAR to environmental pollutants. In addition, Wang et al. [5] have demonstrated that the administration of cypermethrin during puberty has resulted in a disruption of testosterone synthesis by setting down the expression of the StAR gene. However, the overproduction of ROS observed on the malathion group causes mitochondrial membrane damage with a consequent imbalance in the level of StAR mRNA expression, inducing a reduction in cholesterol transport and testicular steroid formation in mice. In addition, the transport of cholesterol from the outer mitochondrial membrane to the inner membrane, the primary step of steroidogenesis, performed by the steroidogenic acute regulatory protein (StAR), is the mainly essential step in steroidogenesis [40].

As soon as it reaches the inner mitochondrial membrane, cholesterol and under the action of a key enzyme regulating steroidogenesis P450scc to produce pregnenolone [41] Our results showed that malathion induce a significant decrease of P450scc enzyme level. Fauser, showed the decrease in the level of P450scc can be attributed to a depletion of cholesterol availability that is due to a reduced level of FSH and $\mathrm{LH}$ [42]. In consequence, testosterone synthesis attenuation can be another results of decreased expression of P450scc enzyme. Recent studies in rats suggest that exposure to deltamethrin decreases steroidogenesis by directly inhibiting the expression of StAR and P450scc enzyme [43].

On the other hand, 3ß-HSD and 17ß-HSD, enzymes which can play a crucial role in testosterone biosynthesis. $3 ß-H S D$ convert's pregnenolone to progesterone, 17 hydroxypregnenolone to 17-hydroxyprogesterone (17-OHP), dehydroepiandrosterone (DHEA) to androstenedione, 17 ßHSD transformed androstenedione to testosterone in the smooth endoplasmic reticulum. A singnificant reduction of
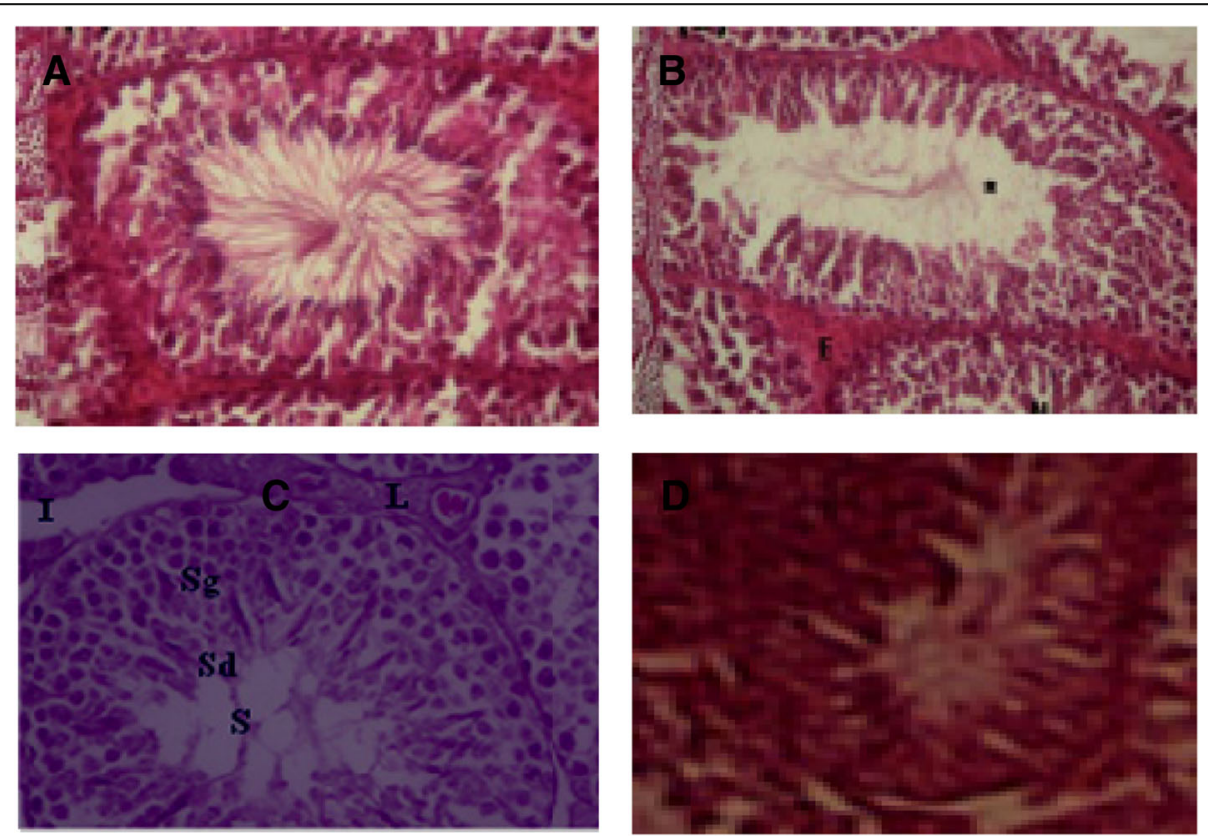

Fig. 6 Histological changes induced by subchronic malathion exposure (200 mg/kg/b.w., p.o.) during 30 days (b), Normal architecture in control group (a), LSEO group (c) and coadministration of M+ LSEO (d); (X400). L: leidigs cells; I: Interstitial space; Sg: Spermatogonia; Sd: Spermatid; S: Spermatozoa; *: decrease of spermatozoa density 

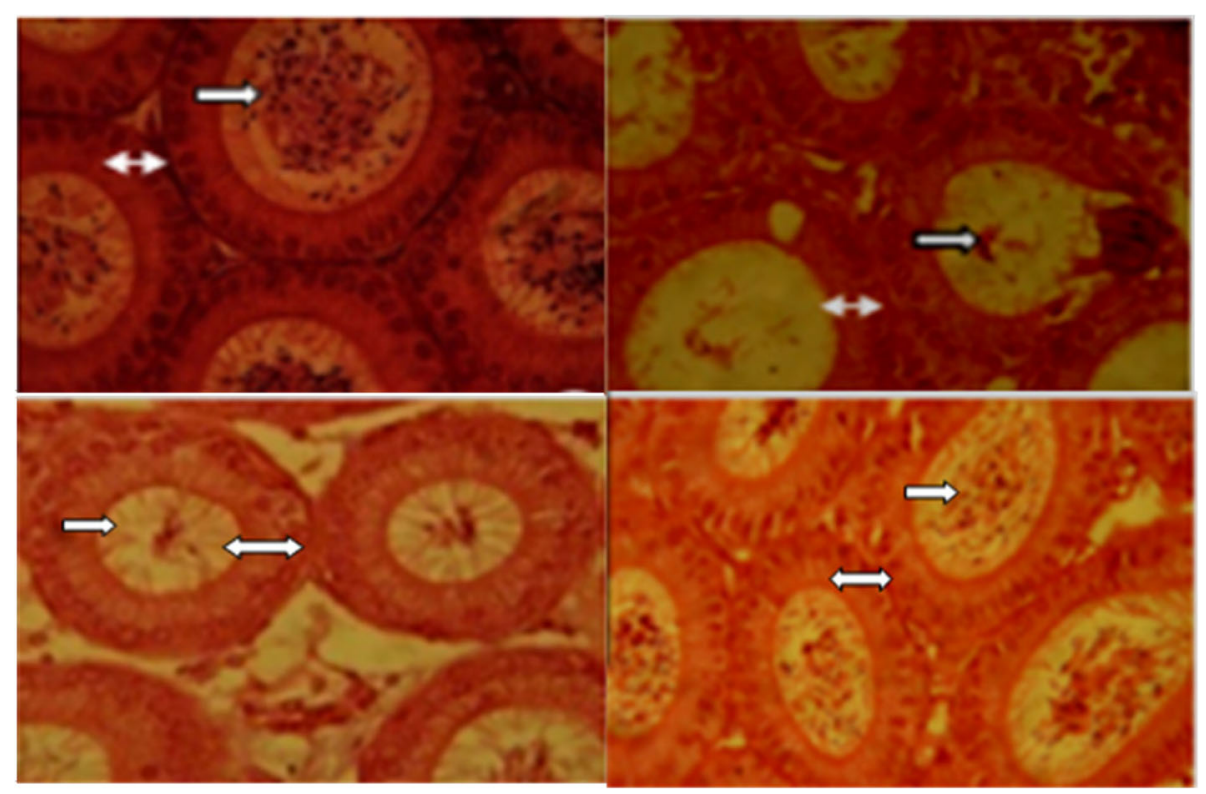

$=\quad:$ Lumen of the epididymis

- : Basal epithelial membrane

Fig. 7 Histomorphology of epididymis observed under light microscope (400 magnification). (a) Control, (b) Malathion treated, (c) LSEO, (d) M + LSEO. : Lumen of the epididymis.: Basal epithelial membrane

activity and expression these enzymes were also noted in malathion-treated mice compared to control group. In part, this reduction of $3 ß-H S D$ and $17 ß-H S D$ gene expression indicates a possible role of these genes to reduce testosterone level in male mice following malathion exposure, and in the other part, may be due also to the diminished expression of StAR. [41]. Ours results are consistent with and in agreement with other studies that have shown that exposure to malathion induces a disturbance of steroidogenesis and an imbalance of antioxidant enzymes [44].

We have been previously reported in our later studies that malathion induced oxidative stress in many organ systems such as liver [10], kidney [10], brain [45], and testis [3]. More importantly, we showed that LSEO significantly attenuated malathion-induced oxidative stress. Malathioninduced oxidative stress has been previously shown to be attenuated by many medicinal plant extracts such as Olea europaea $L$. However, we can suggest that our extract can attenuate the process of lipid peroxidation and/or antioxidant enzymes depletion implicated in the pathogenesis of malathion-induced reproductive damage.

On the other hand, using the DPPH radical-scavenging assay we showed that $L$. stoechas essential oils had an elevated scavenging capacity which may be correlated to the existence of phenolic compounds [46]. These letter, are the primal source of their antioxidant capacity, by scavenging free radicals as hydroxyl radical $\left(\mathrm{OH}^{\circ}\right)$, which is the major cause of lipid peroxidation. However, its well known that sperm cells membranes are rich in polyunsaturated fatty acids and are very susceptible to free radical attack. Lipid peroxidation of sperm cell membranes is one type of cell damage induced by ROS, which causes an increase in membrane permeability, a disruption in respiratory chain and ATP production, as well as a decrease in phosphorylation of axonemal proteins. Malathion induced a decrease of the sperm quality might be due to the lessening of antioxidant enzyme activities and/or ROS accumulation. Free radical-induced sperm motility decrease was most probably due to a rapid loss of intracellular ATP, which altered axoneme arrangement and caused tail deformity [47].

Injury of cell DNA induced by ROS production led to the formation of some peroxidation products such as 8-oxo-7,8 dihydroxyguanosine, which cause disintegration and have a mutagenic consequence [48]. Higher DNA damage of sperm has been reported to reduce male fertility and antioxidants could be used to alleviate male infertility [49].

\section{Conclusions}

We have evidently established that LSEO protect in opposition to malathion-induced steroidogenesis disruptions and oxidative stress in the reproductive function. This repro-protection offered by LSEO may be correlated in part to its antioxidant properties. This research supports the therapeutic potential of LSEO for prevention/treatment of reproductive-toxicity and should be further explored in clinical studies. 


\section{Abbreviations}

$17 \beta$ HSD: $17 \beta$-Hydroxysteroid dehydrogenase; $3 \beta$ HSD: $3 \beta$-Hydroxysteroid dehydrogenase; CTR: Control group; FSH: Follicle-stimulating hormone; LH: Luteinizing hormone; LPO: Lipid peroxidation; LSEO: Lavandula stoechas Essential Oils; M: Malathion; MDA: Malonedialdehyde;

OPs: Organophosphorus; OS: Oxidative stress; ROS: Reactive oxygenated species; StAR: Steroidogenic acute regulatory protein; TBARS: Thiobarbituric acid-reactive substances; WHO: World Health Organization

\section{Acknowledgements}

Financial support of the Tunisian Ministry of Higher Education and Scientific Research is gratefully acknowledged. Financial disclosures: none declared.

\section{Funding}

The study was funded by Tunisian Ministry of Higher Education and Scientific Research.

\section{Availability of data and materials}

All data and materials are contained and described within the manuscript.

\section{Authors' contributions}

SS coordinated data collection, carried out the analyses, drafted the initial manuscript, and approved the final manuscript as submitted, conceptualized and designed the study. KR statistic analysis and participate to biochemical essays. DG participates to biochemical and molecular assays. OL participates to biochemical and molecular assays. HS developed the propagation model and calculated the exposure values, reviewed and revised the manuscript, and approved the final manuscript as submitted. LM conceptualized and designed the study, obtained funding, reviewed and revised the manuscript and approved the final manuscript as submitted.

\section{Ethics approval and consent to participate}

Animals were cared for in compliance with the code of practice for the Care and Use of Animals for Scientific Purposes. Approval for these experiments was obtained from the Medical Ethical Committee for the Care and Use of Laboratory Animals of Pasteur Institute of Tunis (approval number: LNFP/Pro 152,012). The experimental protocols were approved by the Faculty Ethics Committee (Faculty of Sciences, Tunis, Tunisia).

\section{Consent for publication}

This information is not relevant.

\section{Competing interests}

The authors declare that they have no competing interests.

\section{Publisher's Note}

Springer Nature remains neutral with regard to jurisdictional claims in published maps and institutional affiliations.

\section{Received: 30 March 2018 Accepted: 15 October 2018} Published online: 08 November 2018

\section{References}

1. Afifi NA, Ramadan A, Ae-Aziz MI, Saki EE. Influence of dimethoate on testicular and epididymal organs, testosterone plasma level and their tissue residues in rats. Dtsch Tierartl Wschr. 1991;98:419-23.

2. Walsh LP, McCornick C, Martin C, Stocco DM. Roundup inhibits steroidogenesis by disrupting steroidogenic acute regulatory (StAR) protein expression. Environ Health Perspect. 2000;108:769-76.

3. Selmi S, El-Fazaa S, Tounsi H, Safra I, Abdellaoui A, Rjeibi MR, Gharbi N. Histopathological, biochemical and molecular changes of reproductive function after malathion exposure of prepubertal male mice. RSC Adv. 2015; 5:13743.

4. Sayim F. Histopathological effects of dimethoate on testes of rats. Bull Environ Contam Toxicol. 2007;78:479-84.

5. Wang H, Wang Q, Zhao XF, Liu P, Meng XH, Yu T, et al. Cypermethrin exposure during puberty disrupts testosterone synthesis via downregulating StAR in mouse testes. Arch Toxicol. 2010;84:53-61.

6. Al-Attar AM. Effect of grapeseed oil on diazinon-induced physiological and histopathological alterations in rats. Saudi J Biol Sci. 2015;22:284-92.
7. World Health Organization Geneva. WHO: expert committee on diabetes mellitus: second report. World Health Organ Tech Rep Ser 646. 1980:1-80.

8. Gamez MJ, Jimenez J, Risco S, Zarzuelo A. Hypoglycemic activity in various species of the genus Lavandula. Part 1: Lavandula stoechas L. and Lavandulamultifida L. Pharmazie. 1987;42:706-7.

9. Sebai H, Selmi S, Rtibi K, Souli A, Gharbi N, Sakly M. Lavender (Lavandula stoechas L.) essential oils attenuate hyperglycemia and protect against oxidative stress in alloxan induced diabetic rats. Lipids Health Dis. 2013;12:189.

10. Selmi S, Jallouli M, Gharbi N, Marzouki L. Hepatoprotective and Renoprotective effects of lavender (Lavandula stoechas L.) essential oils against Malathion-induced oxidative stress in young male mice. J Med Food. 2015;18(10):1103-11

11. Vega SG, Guzman P, Garcia L. Sperm shape abnormality and urine mutagenicity in mice treated with niclosamide. Mutat Res. 1988;204:269-76.

12. Kvist U, Bjorndahl L. Manual on basic semen analysis, ESHRE monographs 2. Oxford: Oxford University Press; 2002.

13. Tardif S, Laforest JP, Comier N. The importance of porcine sperm parameters on fertility in vivo. Theriogenology. 1999;52:447-59.

14. WHO. Laboratory manual for the examination of human semen and semencervical mucus interaction, 4th edn. Cambridge: University Press; 2001.

15. Seed J, Chapin RE, Clegg ED. Methods for assessing sperm motility, morphology, and counts in the rat, rabbit, and dog: a consensus report. ILSI risk science institute expert working group on sperm evaluation. Reprod Toxicol. 1996;10:237-44.

16. Filler R. Methods for evaluation of rats epididymal sperm morphology. In: Chapin RE, Heindel JH, editors. Male reproductive toxicology. San Diego: Acad. Press. Inc.; 1993. p. 334-43.

17. Begue JA, Aust SD. Microsomal lipid peroxidation. Methods Enzymol. 1978; 52:302-10.

18. Dingeon B, Ferry JP, Roullet A. Auto analysis of blood sugar by Trinder's method. Ann Biol. 1975;33:3-13.

19. Hu ML, Dillard CJ. Plasma SH and GSH measurement. Methods Enzymol. 1994;233:385-7.

20. Misra HP, Fridovich I. The role of superoxide anion in the autoxidation of epinephrine and simple assay for superoxide dismutase. J Biol Chem. 1972; 247:3170-5.

21. Spitz D, Oberley L. An assay for superoxide dismutase activity in mammalian tissue homogenates. Anal Biochem. 1989:179:8-18.

22. Aebi H. Catalase in vitro. Methods Enzymol. 1984;105:121-6.

23. Flohe L, Gunzler WA. Assays of glutathione peroxidase. Methods Enzymol. 1994;105:114-21.

24. Bradford MM. A rapid and sensitive method for the quantitation of microgram quantities of protein utilizing the principal of protein-dye binding. Anal Biochem. 1976;72:248-54

25. Chapin RE, Harris MW, Davis BJ, Ward SM, Wilson RE, Mauney MA, et al. The effects of perinatal/juvenile methoxychlor on adult rat nervous, immune and reproductive system function. Fundam Appl Toxicol. 1997;40:138-57.

26. Takahashi O, Oishi S. Testicular toxicity of dietary 2, 2-bis (4hydroxyphenyl) propane (bisphenol a) in F344 rat. Arch Toxicol. 2001;75:42-51.

27. Schrade SM. Man and the workplace: assessing his reproductive health. Chem Health. 2003;Saf:11-6.

28. Dohle GR, Smith M, Weber RFA. Androgens and male infertility. World J Urol. 2003;21:341-5.

29. Wylie K, Rees M, Hackett G, Anderson R, Bouloux PM, Cust M. Androgens, health and sexuality in women and men. Maturitas. 2010;67:275-89.

30. Jana K, Samanta PK. Evaluation of single intratesticular injection of calcium chloride for nonsurgical sterilization in adult albino rats. Contraception. 2006:73:289-300.

31. Kose E, Sarsilmaz M, Meydan S, Sonmez M, Kus I, Kavakli A. The effect of lavender oil on serum testosterone levels and epididymal sperm characteristics of formaldehyde treated male rats. Eur Rev Med Pharmacol Sci. 2011;15:538-42.

32. Payne $A H$, Hales DB. Overview of steroidogenic enzymes in the pathway from cholesterol to active steroid hormones. Endocr Rev. 2004:25:947-70.

33. Clark BJ, Wells J, King SR, Stocco DM. The purification, cloning, and expression of a novel luteinizing hormone-induced mitochondrial protein in MA-10 mouse Leydig tumor cells. Characterization of the steroidogenic acute regulatory protein (StAR). J Biol Chem. 1994;269:28314-22.

34. Gunnarsson D, Svensson M, Selstam G, Nordberg G. Pronounced induction of testicular PGF 2a and suppression of testosterone by cadmiumprevention by zinc. Toxicology. 2004;200:49-58. 
35. Wang X, Dyson MT, Jo Y, Stocco DM. Inhibition of cycloxygenase-2 activity enhances steroidogenesis and steroidogenic acute regulatory gene expression in MA-10 mouse Leydig cells. Endocrinology. 2003;144:3368-75.

36. Chen H, Liu J, Luo L, Baig MU, Kim JM, Zirkin BR. Vitamin E, aging and Leydig cell steroidogenesis. Exp Gerontol. 2005;40:728-36.

37. Murugesan P, Baladaneshi M, Balasubramanian K, Arunakaran J. Effects of polychlorinated biphenyl (Aroclor 1254) on steroidogenesis and antioxidant system in cultured adult rat Leydig cells. J Endocrinol. 2007;192:325-38.

38. Cao G, Zhao L, Strangle H, Hasegawa T, Richardson JA, Parker KL, et al. Developmental and hormonal regulation of murine scavenger receptor, class B, type 1. Mol Endocrinol. 1999;13:1460-73.

39. Barlow NJ, Phillips SI, Wallace DC, Gaido WK, Foster PMD. Qunatitative changes in gene expression in fetal rat testis following exposure to di(n-butyl) phathalate. Toxicol Sci. 2003;73:431-51.

40. Stocco DM. StAR protein and the regulation of steroid hormone biosynthesis. Annu Rev Physiol. 2001;63:193-213.

41. Miller WL. Molecular biology of steroid hormone synthesis. Endocr Rev. 1988;9:295-318

42. Fauser BCJM. Molecular biology of steroidogenesis. In: Molecular biology in the reproductive medicine. New York: Parthenon Publishing; 1999. p. 234-51.

43. Mariana A, Graciela EH, Marcela NG, Susana MG, Ana LE, Mari'a JT, Carlos AM. Pesticide-induced decrease in rat testicular steroidogenesis is differentially prevented by lipoate and tocopherol. Ecotoxicol Environ Saf. 2013:91:129-38.

44. Kumar V, Chakraborty A, Viswanath G, Roy P. Androgenic endocrine disruptors in wastewater treatment plant effluents in India: their influence on reproductive processes and systemic toxicity in male rats. Toxicol Appl Pharmacol. 2007:226(1):60-3.

45. Selmi S, El-Fazaa S, Gharbi N. Oxidative stress and cholinesterase inhibition in plasma, erythrocyte and brain of rats' pups following lactational exposure to malathion. Environ Toxicol Pharmacol. 2012;34:753-60.

46. Menezo YJ, Hazout A, Panteix G, Robert F, Rollet J, Cohen Barcrie P, Chapuis F, Clement P, Benkhalifa M. Antioxidants to reduce sperm DNA fragmentation: an unexpected adverse effect. Reprod Biomed Online. 2007; 14:418-21

47. Agarwal A, Makker K, Sharma R. Clinical relevance of oxidative stress in male factor infertility: an update. Am J Reprod Immunol. 2008;59(1):2-11.

48. Silva JP, Coutinho OP. Free radicals in the regulation of damage and cell death - basic mechanisms and prevention. Drug Discov Ther. 2010;4(3):14467

49. Greco E, lacobelli M, Rienzi L, Ubaldi F, Ferrero S, Tesarik J. Reduction of the incidence of sperm DNA fragmentation by oral antioxidant treatment. J Androl. 2005;26:349-53.

Ready to submit your research? Choose BMC and benefit from:

- fast, convenient online submission

- thorough peer review by experienced researchers in your field

- rapid publication on acceptance

- support for research data, including large and complex data types

- gold Open Access which fosters wider collaboration and increased citations

- maximum visibility for your research: over $100 \mathrm{M}$ website views per year

At $\mathrm{BMC}$, research is always in progress.

Learn more biomedcentral.com/submissions 